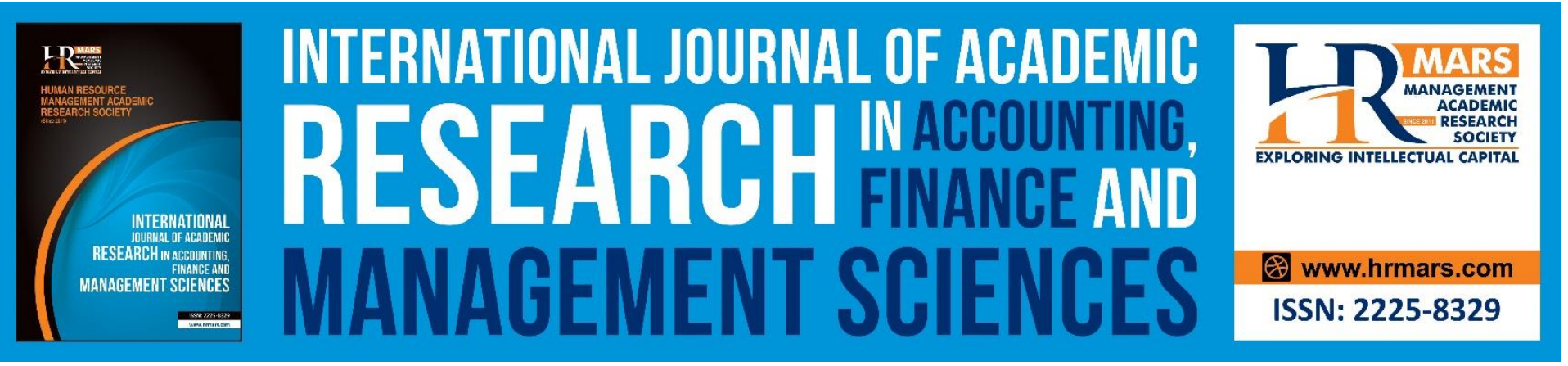

\title{
Recognize the Sticky Costs Behavior
}

\section{Muhammad Yassein Rahahle}

To Link this Article: http://dx.doi.org/10.6007/IJARAFMS/v11-i2/10487

DOI:10.6007/IJARAFMS /v11-i2/10487

Received: 15 March 2021, Revised: 19 April 2021, Accepted: 30 April 2021

Published Online: 20 May 2021

In-Text Citation: (Rahahle, 2021)

To Cite this Article: Rahahle, M. Y. (2021). Recognize the Sticky Costs Behavior. International Journal of Academic Research in Accounting Finance and Management Sciences, 11(2), 186-201.

Copyright: (C) 2021 The Author(s)

Published by Human Resource Management Academic Research Society (www.hrmars.com)

This article is published under the Creative Commons Attribution (CC BY 4.0) license. Anyone may reproduce, distribute, translate and create derivative works of this article (for both commercial and non-commercial purposes), subject to full attribution to the original publication and authors. The full terms of this license may be seen

at: http://creativecommons.org/licences/by/4.0/legalcode

Vol. 11, No. 2, 2021, Pg. 186 - 201

http://hrmars.com/index.php/pages/detail/IJARAFMS

JOURNAL HOMEPAGE

Full Terms \& Conditions of access and use can be found at http://hrmars.com/index.php/pages/detail/publication-ethics 


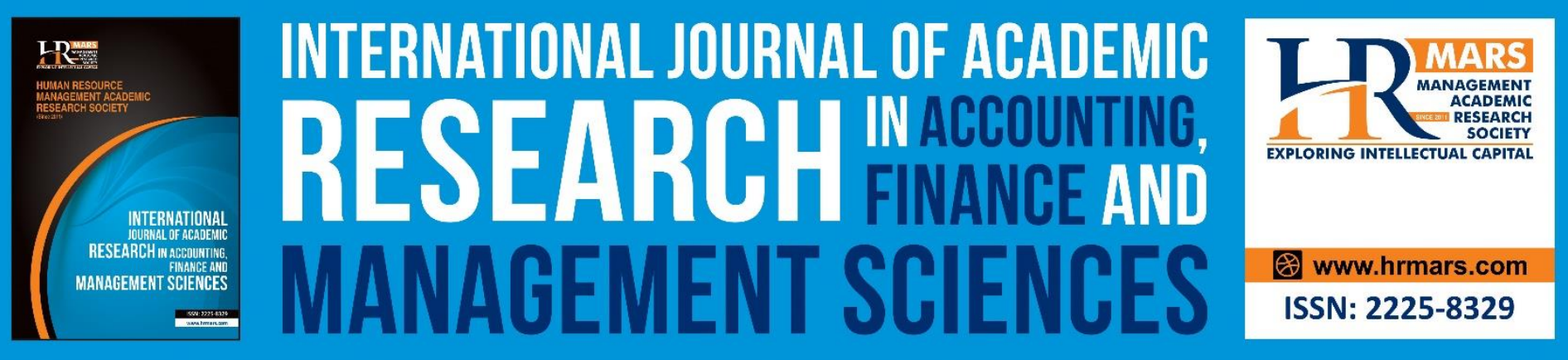

\title{
Recognize the Sticky Costs Behavior
}

\author{
Muhammad Yassein Rahahle
}

Al albayt University-Jordan

Email: Myskr65@yahoo.com

\begin{abstract}
The study aimed to identify the level of the accountants' awareness of the concepts and nature of the phenomenon of asymmetric costs and its sticky behavior, and to reveal the causes and factors that lead to its occurrence, and to propose solutions to avoid it.

The study followed the descriptive and analytical approach, study population consisted of (56) companies that include Jordanian industrial companies listed on the Amman Stock Exchange. The questionnaire was used to collect primary data; the numbers of the questionnaires that are retrieved and valid for analysis were (168).

The study found that there is a medium degree of awareness, understanding and knowledge of the concepts and merits' frameworks of the sticky and asymmetric costs phenomenon in a medium degree, furthermore, there is a high degree of awareness for the causes and factors that lead to the existence of a sticky behavior case and asymmetric costs, and that there is an awareness of the appropriate solutions that have been proposed, which through it, we can avoid sticky behavior of costs in a moderate degree.

The study recommended holding courses and workshops on sticky costs for stakeholders whose work nature requires knowledge and understanding of the rationale for sticky cost behavior, with the aim of enhancing their awareness and serving the corporate goals. And that companies analyze the reasons for the sticky behavior of costs and their asymmetric, as well as study the proposed solutions, and review their policies and regulations related to controlling the relationship between owners and managers, in order to reduce cases of conflict of interest, and benefit from the expertise of legal advisors related to the organization of labor, following appropriate policies in the acquisition of fixed assets and stock.
\end{abstract}

\section{Introduction}

Cost is one of the important considerations that are studied and analyzed when making decisions, especially in industrial companies. The quality of decisions related to production activities that are taken is based on this. The decisions and plans adopted by companies vary according to the results of the analysis of the cost of each decision or plan, where companies may resort to alternative plans and decisions due to the high cost of decisions. 
INTERNATIONAL JOURNAL OF ACADEMIC RESEARCH IN ACCOUNTING, FINANCE AND MANAGEMENT SCIENCES

Vol. 11, No. 2, 2021, E-ISSN: 2225-8329 @ 2021 HRMARS

Therefore, decision makers and managers in companies must have the correct knowledge and understanding of the behavior of costs, in order to make appropriate decisions about the cost of activities and products, companies are supposed to have accounting systems that are capable of providing the accounting information that departments need related to costs, analyzing their behavior and the financial consequences that are associated with them when making decisions, which improves departments' understanding and awareness of the nature and behavior of the costs included in the decisions and the possibility of future predictability of the results and goals that are expected to be achieved.

\section{Problem Statement}

Recent studies have shown that the behavior of costs has become inconsistent with the traditional assumption that the level of costs and the volume of activity change together in a linear manner, as it was found that the increase in costs resulting from the expansion of companies' business activities are greater than the cost from the decrease in these works (Xu \& Sim, 2017).

Therefore, it has become a duty for managers and accountants to pay attention to studying this relationship and tracking the behavior of costs, based on the fact that understanding the motive behavior of costs towards a change in the level of activity provides evidence of the correctness of decision-making, including budget decisions (Abu-Serdaneh, 2014). A new phenomenon has emerged in which costs increase more when sales increase than decrease when sales decrease by a similar amount and this behavior was known as asymmetric behavior of costs (Sun et al., 2019). This raises questions about the perception and understanding of those involved in asymmetric costs behavior and is expressed as sticky costs.

The problem of the study can be presented in detail through the following questions:

- Is there an awareness of the nature and concepts of the phenomenon of asymmetric costs and its sticky behavior?

- What are the reasons and determinants that lead to the occurrence of sticky behavior of costs?

- Are there possible solutions available to avoid the sticky behavior of costs?

\section{Study Objectives}

- Identifying the level of awareness of accountants of the concepts and nature of the phenomenon of asymmetric costs and its sticky behavior.

- Detecting the reasons and factors that lead to the occurrence of sticky behavior of costs and their asymmetric.

- Suggesting solutions to avoid the phenomenon of asymmetric costs.

\section{Study Significance}

The current study is considered modern and unique in terms of its subject matter, especially in light of the scarcity of studies on the issue of asymmetric costs, and therefore it will have an added value from a scientific point of view in providing updated information, which will open horizons for researchers to research in the field of sticky costs and conduct more studies in this field. This study will also enhance the understanding and awareness of accountants, financial analysts and managers of the nature of sticky costs, and thus take them into account when making decisions in industrial companies, which will make decisions more rational and realistic, and that the administrations take the solutions proposed by the study to avoid the sticky behavior of costs will reduce or prevent 
INTERNATIONAL JOURNAL OF ACADEMIC RESEARCH IN ACCOUNTING, FINANCE AND

MANAGEMENT SCIENCES

Vol. 11, No. 2, 2021, E-ISSN: 2225-8329 @ 2021 HRMARS

asymmetric costs, and this will lead to achieving financial benefits and reducing the cost of corporate decisions and activities.

\section{Study Hypotheses}

HO1: There is no understanding of the nature and concepts of the phenomenon of asymmetric costs. $\mathrm{HO} 2$ : There is no understanding of the causes and factors for the occurrence of asymmetric costs.

HO3: There is no realization of possible solutions to avoid sticky costs behavior.

\section{Theoretical Framework}

\section{Asymmetric (Sticky) Costs}

The behavior of costs is a fundamental issue in the field of management and cost accounting, because of its direct impact on managers' decision-making, and this behavior is affected by the methods that are used by cost accountants or financial analysts directly, such as the activity-based costing system and the analysis of cost, volume and profits, it is assumed that there is a relationship between costs and activities based on the fact that costs change according to the rate of change in activities (Da Silva et al., 2018).

Sticky costs are defined as the costs that decrease with the decrease in the volume of activity less than their percentage increases when the volume of activity increases with the same percentage as the decrease in its volume. In other words, its increase or decrease as a result of the increase or decrease in the volume of activity by the same of asymmetric percentage (Anderson, Banker \& Janakiraman, 2003). It is called asymmetric behavior of costs, as this behavior is defined as the phenomenon in which costs increase more when sales increase than decrease when sales decrease by a similar amount (Sun et al., 2019). Several previous studies have investigated the idea of sticky costs, for example, (Banker, Byzalov \& Chen, 2013) considered sticky costs as a complex phenomenon and defined as the reduced cost of less than (1) percent when sales fell by (1) percent.

The measurement of changes in costs depend only on the rate of change in the level of activity and not on changes in trend, but some believe that costs increase more through volume activity, and costs become sticky behavior when the amount in costs associated with increasing volume, greater than the decrease in associated costs with the same reduction in volume, in addition, any reduction in volume of activity, a company with a sticky costs compared to companies without sticky costs will have a greater reduction in income (Jamkarani \& Lalbar, 2016).

Topics in sticky cost, also called asymmetric cost behavior, are an important area of discussion in both accounting and economic research, and are related to the motivations of managers (Xue \& Hong, 2016, p. 44).

The asymmetric costs behavior model was first developed by (Anderson et al., 2003), which states that there are costs that are significantly asymmetric related to changes in sales revenue, this matter in this field has drawn attention to the existence of stickiness in cost. During this period, research and debate were active as to whether these costs were really attached (Cheung et al., 2016).

Recently, some studies have demonstrated practical proof that this traditional assumption about the relationship between costs and activity is not linear, and that there are some elements of costs whose increase is greater than the percentage increase in the volume of activity than if it decreases when the volume of activity is reduced as a result of asymmetric behavior in costs. These costs are called Sticky Cost, which are costs that occur if the magnitude of the increase in costs associated with an 
increase in the volume of activity is greater than the size of the decrease in costs associated with a similar decrease in the volume of activity.

when sales decrease, managers may decide to dispose of some unusable resources; however, they avoid removing resources when the termination is temporary, thus, when there is no decreasing in resource when sales decrease, the company incurs high costs of adjustment, such as laying off employees, and managers interested in meeting profit targets can accelerate resource cuts even in times of temporary decline in sales, this accelerated reduction in resources can have the consequences of further reduction in costs. Therefore, when managers have incentives to achieve goals, they are more likely to reduce the degree of asymmetric costs (Kama \& Weiss, 2013).

Anderson et al (2003) presented an analysis of the behavior of asymmetric costs by examining selling costs and overhead costs against the change in the level of sales, (ABJ) model was used, based on the natural logarithm of the rate of change in selling, general and administrative costs in relation to the change in sales revenue. It was concluded that costs increased by $(0.55 \%)$ for each (1\%) increase in sales, but decreased by $(0.35 \%)$ for each $(1 \%)$ decrease in sales. The study presented a reliable quantitative model for analyzing asymmetric costs.

Such sticky (asymmetric) behavior of costs is reflected in the quality of information and its contents resulting from the management accounting information system as a result of its impact on the accuracy of estimates of cost items and thus is reflected on all decisions within the enterprise, including profitability decisions, performance evaluation, planning processes, control and decisionmaking (Mohammad, 2020,p. 5).

\section{Factors Causing Sticky Costs}

Several factors that lead to sticky costs, as follows (Banker et al., 2013; Maghid \& Al-Issa, 2017):

High levels of fixed assets.

High levels of stock.

Increase the number of employees.

Intensifying competition across the industry.

- Excess capacity.

- Consecutive losses.

- Labor protection legislation at the state level.

- The pattern of management behavior and administrative decisions that prevent the dismissal of individuals due to the management's desire to preserve the expertise available to it from human resources.

- Laws and regulations related to employment and labor unions and federations that prevent the disposal of workers except in specific circumstances and conditions.

- The administration's lack of intention to dismiss individuals.

- The tendency of managers to take the kind of decisions that enhance and maximize their personal benefits and interests, regardless of the economic interest of the enterprise.

- The desire to maintain untapped resources beyond the optimal needs, i.e., beyond what is needed and required by the activities in the facility, in order to maintain the influence and powers of managers and as managers increase selling, general and administrative costs rapidly when sales increase and reduce them slowly when sales decline. 
INTERNATIONAL JOURNAL OF ACADEMIC RESEARCH IN ACCOUNTING, FINANCE AND

MANAGEMENT SCIENCES

Vol. 11, No. 2, 2021, E-ISSN: 2225-8329 @ 2021 HRMARS

- Managers' realization that any reduction in resources will reflect positively on the interests of the owners and not on their personal and monetary interests, which prompts them not to reduce costs, reduce employment, or reduce unused resources.

- The agency problem is one of the most important causes of sticky costs, as managers can make appropriate solutions and immediately make decisions, contributions and interventions that reduce cost stickiness.

\section{Cost Items that Tend to Asymmetric Behavior}

Most of the studies that analyzed the following items to study the asymmetric behavior of costs, as follows (Ballas , Naoum \& Vlismas, 2020; Anestaki, 2020; Radhika \& Satuluri, 2019; Gu, Tang \&Wu, 2020; Hur , Kim\& Cheung, 2019):

\section{Selling, General and Administrative Costs}

It includes non-productive operating expenses, such as the cost of storing goods, preparing them for sale, advertising and promoting them, and working to deliver them to the buyer. In other words, they consist of all expenses that apply to the company's overall business operations. The asymmetric phenomenon is found in selling, general and administrative costs and is determined by the company's strategic direction as it is considered an important contributor factor to determining the degree of asymmetric.

\section{Cost of Goods Sold (Costs of Sales)}

They are the costs directly related to the production of goods or services in the company, such as: material costs, rent and employee salaries.

\section{Operational Costs}

Operational costs include all recurring expenses that the company incurs in order to continue its business and operations.

\section{Working Hours (Labor Cost)}

The state of labor cost behavior and its impact varies according to the nature of its ownership (private or governmental), and these impacts are stronger in companies with weak markets and during periods when government officials are promoted.

\section{Research and Development Costs}

The behavior of this type varies according to the characteristics of the Executive Director. Overconfident managers tend not to take action to reduce research and development costs even when sales are low.

\section{Study Methodology}

This study relied on the descriptive-analytical approach in order to identify the opinions of respondents in industrial companies about the levels of understanding and awareness of sticky costs, the causes and factors of their occurrence and the proposed solutions to avoid them. 
INTERNATIONAL JOURNAL OF ACADEMIC RESEARCH IN ACCOUNTING, FINANCE AND MANAGEMENT SCIENCES

Vol. 11, No. 2, 2021, E-ISSN: 2225-8329 @ 2021 HRMARS

\section{The Study Population}

The researcher used the comprehensive inventory method to determine the study population, which consisted of the Jordanian industrial joint stock companies listed on the Amman Stock Exchange, which turned out to be (56) companies, where the researcher distributed (175) questionnaires to financial managers, their assistants, heads of accounting departments and accountants in those companies as they are the sampling unit and in a random way, (171) questionnaires were retrieved, and after reviewing the questionnaires, it was found that there are (3) questionnaires that are not valid for statistical analysis due to lack or inaccuracy of filling, and thus the number of questionnaires valid for analysis was (168), and the following is a presentation of the distribution of the respondents according to personal variables (educational qualification, scientific specialization, number of years of experience, job title according to the organizational structure):

Table (1) Analysis of the Demographic Characteristics of the Respondents

\begin{tabular}{|l|l|l|l|}
\hline Percentage & Repetition & Variable & \multirow{5}{*}{ Specialization } \\
\hline $68 \%$ & 115 & Accounting & \\
\hline $15 \%$ & 25 & Business Administration & \\
\hline $12 \%$ & 21 & Banking and Financial Sciences & \multirow{3}{*}{ Qualification } \\
\hline $3 \%$ & 5 & Economy & \\
\hline $1 \%$ & 2 & Other & \multirow{3}{*}{ Years of Experience } \\
\hline $90 \%$ & 152 & Bachelor & \\
\hline $6 \%$ & 12 & Master & \\
\hline $3 \%$ & 4 & Doctorate & \multirow{3}{*}{ Job Title } \\
\hline $11 \%$ & 18 & Less than 5 years & \\
\hline $14 \%$ & 23 & 5 to less than 10 years & \\
\hline $40 \%$ & 68 & 10 to less than 15 years old & \\
\hline $17 \%$ & 28 & 15 to less than 20 years & \\
\hline $18 \%$ & 31 & 20 years and over & \\
\hline $10 \%$ & 17 & Financial Manager & \\
\hline $11.3 \%$ & 19 & Financial Manager Assistant & \\
\hline $15 \%$ & 25 & Head of Accounting Department & \\
\hline $63.7 \%$ & 107 & Accountant & \\
\hline
\end{tabular}

Table (1) indicates that respondents have knowledge within scientific disciplines, appropriate academic qualifications, and sufficient experience to enable them to understand the contents of the questionnaire and answer its phrases. Also, the participation of respondents from different job levels such as financial managers and their assistants contributes to obtaining a diversity of answers, and enhances confidence in data reliability.

\section{Collection Sources Data}

This study relied on two methods of data collection:

A. Secondary Sources: They are the data available in electronic databases from Arab and foreign scientific books and periodicals related to the subject of the study and previous scientific theses related to the research. 
INTERNATIONAL JOURNAL OF ACADEMIC RESEARCH IN ACCOUNTING, FINANCE AND MANAGEMENT SCIENCES

Vol. 11, No. 2, 2021, E-ISSN: 2225-8329 @ 2021 HRMARS

B. Primary Sources: The researcher collected data by means of a research questionnaire that was developed specifically for the purposes of this study and which suits the nature and title of the study, its implications have been crystallized by extrapolating the scientific dimensions based on what has been theoretically presented in the study literature, and the following is a detail of the study tool.

\section{Study Tool}

For the purposes of achieving the objectives of the study, a questionnaire was used to collect primary data. The following is a presentation of the components of the questionnaire:

The First Part: It contains the personal data of the individuals who responded to the study questionnaire.

The Second Part: It included the expressions that express the variables of the study and it consisted of three areas as follows:

The First Field: Awareness of the nature of the concepts of the phenomenon of asymmetric costs and its sticky behavior.

The Second Field: The causes and factors that lead to the occurrence of sticky costs.

The Third Area: The proposed solutions to avoid the sticky costs.

\section{Tool Scale}

In order to analyze the data, the five-point Likert scale was used to answer the paragraphs, according to the following scores, which are shown in Table (2):

Table (2): Opinions' Distribution on paragraphs' questionnaire according to the five-point Likert scale

\begin{tabular}{|l|l|l|l|l|l|}
\hline Degree & $\mathbf{5}$ & $\mathbf{4}$ & $\mathbf{3}$ & $\mathbf{2}$ & $\mathbf{1}$ \\
\hline Response & $\begin{array}{l}\text { Strongly } \\
\text { Agree }\end{array}$ & Agree & Neutral & Disagree & $\begin{array}{l}\text { Strongly } \\
\text { Disagree }\end{array}$ \\
\hline
\end{tabular}

With regard to the limits adopted by this study when commenting on the arithmetic mean of the variables contained in the study model, to determine the degree of approval, the researcher identified three levels (high, medium, low) based on the following equation:

Length of period $=$ (maximum alternative - minimum alternative) $/$ number of levels. $(5-1) / 3=4 / 3=1.33$

Thus, the levels are as follows, as they are in Table (3) below, which shows the scale in determining the appropriateness level for the arithmetic mean, in order to benefit from it when commenting on the arithmetic means. 
INTERNATIONAL JOURNAL OF ACADEMIC RESEARCH IN ACCOUNTING, FINANCE AND

MANAGEMENT SCIENCES

Vol. 11, No. 2, 2021, E-ISSN: 2225-8329 @ 2021 HRMARS

Table (3) Scale for Determining the Level of Suitability for the Arithmetic Mean

\begin{tabular}{|l|l|}
\hline Arithmetic Mean & Rating Degree \\
\hline $1-2.33$ & Low \\
\hline $2.34-3.66$ & Medium \\
\hline $3.67-5.00$ & High \\
\hline
\end{tabular}

\section{Stability of the Study Tool}

Cronbach's Alpha coefficient was used to check the internal consistency of the questionnaire as a whole as the most common measure among researchers to achieve this purpose. The results are shown in Table (4) below, which shows that the Cronbach's alpha coefficient for the resolution as a whole.

Table (4) Stability Coefficients (Cronbach's alpha) for all Paragraphs of the Study Dimensions and the Tool as a Whole

\begin{tabular}{|l|l|}
\hline Dimension & Cronbach's alpha Coefficient \\
\hline $\begin{array}{l}\text { Awareness of the nature and concepts of the } \\
\text { phenomenon of asymmetric costs }\end{array}$ & $\mathbf{0 . 7 4}$ \\
\hline Causes and determinants of sticky costs & $\mathbf{0 . 7 1}$ \\
\hline Suggested solutions to avoid sticky costs & $\mathbf{0 . 8 0}$ \\
\hline
\end{tabular}

It is clear from the previous table that the values of Cronbach's alpha coefficients for all dimensions and fields of study were high, as many specialists believe that the value adopted to give a decision regarding the adequacy of Cronbach's alpha coefficient is (70\%) (Sekaran, Bougie 2016), which indicates the stability of the results that can be the result of the study tool when applied.

\section{Virtual Validity}

To ensure the validity of the questionnaire and its constituent expressions of the study variables in an honest and appropriate manner in terms of substance, content, language and form, the questionnaire was presented to a group of specialized arbitrators from the faculty members, who kindly expressed their comments about the terms and phrases of the questionnaire, and the researcher modified them. According to what they indicated until the questionnaire was taken out in its final form.

\section{Statistical Methods}

In order to analyze the primary study data, the following statistical methods were used:

- Descriptive statistics methods such as frequencies, percentages, arithmetic mean and standard deviation.

- One Sample T-test to test the study's hypotheses.

- Cronbach's Alpha coefficient in order to check the internal consistency of the questionnaire items.

\section{Statistical Analysis}

For the purposes of achieving the objectives of the study and analyzing its data, the researcher extracted the arithmetic means of the respondents' opinions about the realization of the nature and 
INTERNATIONAL JOURNAL OF ACADEMIC RESEARCH IN ACCOUNTING, FINANCE AND MANAGEMENT SCIENCES

Vol. 11, No. 2, 2021, E-ISSN: 2225-8329 @ 2021 HRMARS

concepts of the phenomenon of asymmetric costs, the causes and factors of its occurrence and suggestions for avoiding it, and the following is a statistical analysis of that.

- Awareness of the nature and concepts of the phenomenon of asymmetric costs.

Table (5): Arithmetic Means and Standard Deviations of Respondents' Perception of the Nature and Concepts of Sticky Costs

\begin{tabular}{|c|c|c|c|c|}
\hline \multicolumn{2}{|c|}{ Paragraph } & \multirow{2}{*}{\begin{tabular}{|l|}
$\begin{array}{l}\text { Arithmetic } \\
\text { Mean }\end{array}$ \\
4.00 \\
\end{tabular}} & \multirow{2}{*}{$\begin{array}{l}\text { Standard } \\
\text { Deviation } \\
1.12\end{array}$} & \multirow{2}{*}{$\begin{array}{l}\text { Rating } \\
\text { Degree } \\
\text { High }\end{array}$} \\
\hline 1 & $\begin{array}{l}\text { The need to pay attention to understanding cost } \\
\text { behavior is essential to the entities within the } \\
\text { company. }\end{array}$ & & & \\
\hline 2 & $\begin{array}{l}\text { The need to conduct studies and research on topics } \\
\text { related to sticky cost (asymmetric behavior of } \\
\text { costs). }\end{array}$ & 3.88 & 1.16 & High \\
\hline 3 & $\begin{array}{l}\text { A model is used to study and analyze asymmetric } \\
\text { costs behavior. }\end{array}$ & 3.61 & 0.93 & Medium \\
\hline 4 & $\begin{array}{l}\text { Discussions and debates are held about the sticky } \\
\text { behavior of costs when making decisions. }\end{array}$ & 3.64 & 0.85 & Medium \\
\hline 5 & $\begin{array}{l}\text { The phenomenon of sticky costs is complex and } \\
\text { cannot be ignored. }\end{array}$ & 3.45 & 0.88 & Medium \\
\hline 6 & $\begin{array}{l}\text { There are criticisms of the traditional assumption of } \\
\text { the relationship between costs and activity that it is } \\
\text { always linear. }\end{array}$ & 3.43 & 1.03 & Medium \\
\hline 7 & $\begin{array}{l}\text { The increase of some elements of costs is greater } \\
\text { than the percentage increase in the volume of } \\
\text { activity than in the case of its decrease when the } \\
\text { volume of activity is reduced as a result of } \\
\text { asymmetric costs behavior. }\end{array}$ & 3.29 & 0.94 & Medium \\
\hline 8 & $\begin{array}{l}\text { Cost does not respond identically to changes in the } \\
\text { volume of activity up and down. }\end{array}$ & 3.13 & 1.17 & Medium \\
\hline 9 & $\begin{array}{l}\text { The relationship between the behavior of cost of } \\
\text { goods sold, selling and administrative costs and } \\
\text { changes in sales revenue is examined. }\end{array}$ & 2.83 & 0.97 & Medium \\
\hline 10 & $\begin{array}{l}\text { Cases in which costs increase more when sales } \\
\text { increase than decrease when sales decrease and by } \\
\text { a similar amount are studied. }\end{array}$ & 2.80 & 1.00 & Medium \\
\hline 11 & $\begin{array}{l}\text { The cases of the unequal rate of change of costs } \\
\text { and the increase and decrease volume of activity } \\
\text { are searched. }\end{array}$ & 2.00 & 1.11 & Medium \\
\hline \multicolumn{2}{|c|}{ Total Field } & \multicolumn{2}{|l|}{3.26} & Medium \\
\hline
\end{tabular}

Table (5) shows that respondents have a medium degree of awareness, understanding and knowledge of the frameworks of the concepts and reasons for the phenomenon of sticky and 
INTERNATIONAL JOURNAL OF ACADEMIC RESEARCH IN ACCOUNTING, FINANCE AND MANAGEMENT SCIENCES

Vol. 11, No. 2, 2021, E-ISSN: 2225-8329 @ 2021 HRMARS

asymmetric of costs, where the arithmetic mean of their answers reached (3.26), their evaluation was of the need to pay attention to understanding the cost behavior of the parties within the company, and the need to conduct studies and research in topics related to sticky cost (asymmetric behavior of costs) to a high degree. While respondents believe that cases of unequal changes in costs and the increase and decrease of volume of activity are investigated, at an average level, and with an arithmetic mean (2.00), which is the lowest among their answers to this field.

- The Causes and Determinants that Lead to the Occurrence of Sticky Costs

Table (6): Arithmetic Means and Standard Deviations to Understand the Causes and Determinants of the Asymmetric of the Cost

\begin{tabular}{|c|c|c|c|c|}
\hline \multicolumn{2}{|c|}{ Paragraph } & \multirow{2}{*}{$\begin{array}{l}\text { Arithmetic } \\
\text { Mean } \\
4.00\end{array}$} & \multirow{2}{*}{$\begin{array}{l}\text { Standard } \\
\text { Deviation } \\
0.67\end{array}$} & \multirow{2}{*}{$\begin{array}{l}\text { Rating } \\
\text { Degree } \\
\text { High }\end{array}$} \\
\hline 1 & $\begin{array}{l}\text { The agency theory and its related conflict of interests } \\
\text { and viewpoints between the clients (owners) and the } \\
\text { clients (the managers) who manage the company and } \\
\text { take decisions of personal benefit, whether moral or } \\
\text { material. }\end{array}$ & & & \\
\hline 2 & $\begin{array}{l}\text { Costs are not adjusting to fluctuations in sales quickly } \\
\text { enough. }\end{array}$ & 3.95 & 0.43 & High \\
\hline 3 & $\begin{array}{l}\text { The density of assets, especially fixed assets, as it is } \\
\text { difficult to dispose of them during periods of low } \\
\text { revenues, and therefore the company is forced to } \\
\text { keep them until the recovery periods return again. }\end{array}$ & 3.92 & 0.53 & High \\
\hline 4 & $\begin{array}{l}\text { Not to dispense labor in periods of depression, so as } \\
\text { not to have to pay their compensation and bear the } \\
\text { cost of recruitment and training again when the } \\
\text { volume of activity increases again. }\end{array}$ & 3.90 & 045 & High \\
\hline 5 & $\begin{array}{l}\text { Management's predictions and managers' over- } \\
\text { optimism and the resulting over-confidence in their } \\
\text { future estimates about future demand and sales. }\end{array}$ & 3.88 & 068 & High \\
\hline \multirow[t]{3}{*}{6} & $\begin{array}{l}\text { Incompatibility and inconsistency between the } \\
\text { volume of activity and the costs incurred by the } \\
\text { company to reach this volume of activity. }\end{array}$ & 3.87 & 053 & High \\
\hline & $\begin{array}{l}\text { Weak control system as it provides inaccurate } \\
\text { financial reports and information is of low quality, } \\
\text { which limits managers' ability to predict the future, } \\
\text { delaying management's decision to reduce stagnant } \\
\text { resources when demand is expected to decline. }\end{array}$ & 3.85 & 064 & High \\
\hline & Excessive energy is more than activities. & 3.85 & 060 & High \\
\hline 7 & Labor protection legislations. & 3.84 & 064 & High \\
\hline 8 & $\begin{array}{l}\text { Weak application of institutional governance and its } \\
\text { mechanisms. }\end{array}$ & 3.82 & 057 & High \\
\hline
\end{tabular}


INTERNATIONAL JOURNAL OF ACADEMIC RESEARCH IN ACCOUNTING, FINANCE AND MANAGEMENT SCIENCES

Vol. 11, No. 2, 2021, E-ISSN: 2225-8329 @ 2021 HRMARS

\begin{tabular}{|l|l|l|l|l|}
\hline $\mathbf{9}$ & $\begin{array}{l}\text { The nature of the company's activity, as the degree of } \\
\text { asymmetric is highest in industrial, commercial and } \\
\text { then service companies. }\end{array}$ & $\mathbf{3 . 8 1}$ & $\mathbf{0 . 7 7}$ & High \\
\hline $\mathbf{1 0}$ & The company achieved consecutive losses. & $\mathbf{3 . 8 1}$ & $\mathbf{0 . 8 0}$ & High \\
\hline $\mathbf{1 1}$ & $\begin{array}{l}\text { The conditions of the competitive environment in } \\
\text { which the company is living. }\end{array}$ & $\mathbf{2 . 8 0}$ & $\mathbf{. 6 2}$ & High \\
\hline $\mathbf{1 2}$ & $\begin{array}{l}\text { Tax avoidance and the preservation of cash savings } \\
\text { obtained from avoidance, as excess resources even in } \\
\text { the event of reduced activity. }\end{array}$ & $\mathbf{3 . 7 8}$ & $\mathbf{0 . 8 5}$ & High \\
\hline $\mathbf{1 3}$ & Overconfident optimism in companies' mergers. & $\mathbf{3 . 7 7}$ & $\mathbf{0 . 6 9}$ & High \\
\hline Total Field & $\mathbf{3 . 7 9}$ & High \\
\hline
\end{tabular}

Table No. (6) Indicates the respondents' agreement about the causes, factors and determinants that lead to the existence of a case of sticky behavior and asymmetric of costs, and its adoption of sticky behavior, where the arithmetic mean of their answers reached (3.79) in a high degree. The reason for the density of assets, especially fixed assets, as it is difficult to get rid of them during periods of low revenues, and therefore the company is forced to keep them until the recovery periods return again, it is the most important factor from the respondents' point of view, followed by the lack of adjustment of costs with fluctuations in sales quickly, followed by the failure to lay off labor in depression periods, so as not to have to pay its compensation, followed by problems related to conflict of interest between owners and managers as agents of companies' management, while excessive optimism with confidence in cases of companies' mergers was at a high degree and is the least rated within the high category.

- Suggested Solutions to Avoid Sticky Behavior of Costs

Table (7): Arithmetic Means and Standard Deviations of Respondents' Perception of Possible Solutions to Avoid Sticky Behavior of Costs

\begin{tabular}{|c|c|c|c|c|}
\hline \multicolumn{2}{|c|}{ Paragraph } & \multirow{2}{*}{\begin{tabular}{|l|} 
Arithmetic \\
Mean \\
4.00 \\
\end{tabular}} & \multirow{2}{*}{\begin{tabular}{|l|} 
Standard \\
Deviation \\
1.12
\end{tabular}} & \multirow{2}{*}{$\begin{array}{l}\text { Rating } \\
\text { Degree } \\
\text { High }\end{array}$} \\
\hline 1 & $\begin{array}{l}\text { Follow policies trying to maintain moderate levels of } \\
\text { asymmetric of stock. }\end{array}$ & & & \\
\hline 2 & $\begin{array}{l}\text { Take measures to maintain moderate levels of } \\
\text { asymmetric of fixed assets. }\end{array}$ & 3.88 & 1.16 & High \\
\hline 3 & $\begin{array}{l}\text { Attempting to develop plans to provide non-monetary } \\
\text { compensation to employees when they are laid off. }\end{array}$ & 3.61 & 0.93 & Medium \\
\hline 4 & $\begin{array}{l}\text { Managers do not rely on a system of labor with } \\
\text { asymmetric costs behavior. }\end{array}$ & 3.46 & 0.85 & Medium \\
\hline 5 & $\begin{array}{l}\text { Develop regulations that protect the rights of } \\
\text { shareholders in the face of principals to avoid conflict } \\
\text { of interest issues related to agency theory. }\end{array}$ & 3.45 & 0.88 & Medium \\
\hline 6 & $\begin{array}{l}\text { Enhancing financial analysts' awareness of their } \\
\text { earnings' expectations, especially in the event of weak } \\
\text { sales. }\end{array}$ & 3.43 & 1.03 & Medium \\
\hline
\end{tabular}


INTERNATIONAL JOURNAL OF ACADEMIC RESEARCH IN ACCOUNTING, FINANCE AND MANAGEMENT SCIENCES

Vol. 11, No. 2, 2021, E-ISSN: 2225-8329 @ 2021 HRMARS

\begin{tabular}{|c|c|c|c|c|}
\hline 7 & $\begin{array}{l}\text { Work to identify the asymmetric behavior of costs to } \\
\text { provide appropriate information for the planning } \\
\text { process, cost control and rationalize the decisions } \\
\text { taken by management. }\end{array}$ & 3.29 & 0.94 & Medium \\
\hline 8 & $\begin{array}{l}\text { Focusing the administrations' attention on the } \\
\text { asymmetric behavior of the costs and the resulting } \\
\text { effects in order to provide more accurate information } \\
\text { to serve the decisions in these companies. }\end{array}$ & 3.13 & 1.17 & Medium \\
\hline 9 & $\begin{array}{l}\text { Reconsidering the tools for preparing budgets and } \\
\text { rationalizing decisions in light of the asymmetric } \\
\text { behavior of costs. }\end{array}$ & 2.83 & 0.97 & Medium \\
\hline \multicolumn{2}{|c|}{ Total Field } & \multicolumn{2}{|l|}{3.45} & Medium \\
\hline
\end{tabular}

Table No. (7) indicates that respondents believe that the solutions that have been proposed to avoid the sticky behavior of costs are appropriate to a medium degree, as the arithmetic mean was (3.45), where they evaluated the proposed solution by following the policies of trying to maintain moderate levels of stock asymmetry at a high degree, followed by taking measures to maintain moderate levels of asymmetric for fixed assets as one of the solutions and at a high degree as well. While they evaluated the rest of the possible solutions at a medium degree, and among them was a review of the tools for preparing budgets and rationalizing decisions in light of the behavior of costs with the lowest degree within the average category, as it obtained the lowest arithmetic mean within the field.

\section{Testing Hypothesis}

HO1: There is no understanding of the nature and concepts of the phenomenon of asymmetric costs.

To validate this hypothesis, a (One Sample T-test) was conducted as shown in Table (8) below.

Table (8) Results of the Application of the (One Sample T-test) to Provide an understanding of the Nature and Concepts of the Phenomenon of asymmetric Costs

\begin{tabular}{|l|l|l|l|l|l|}
\hline Hypothesis & $\begin{array}{l}\text { Arithmetic } \\
\text { Mean }\end{array}$ & $\mathbf{T}$ & $\begin{array}{l}\text { Freedom } \\
\text { Degrees }\end{array}$ & Sig & Result \\
\hline $\begin{array}{l}\text { There is no understanding of the } \\
\text { nature and concepts of the } \\
\text { asymmetric costs phenomenon. }\end{array}$ & $\mathbf{3 . 2 6}$ & $\mathbf{4 . 5}$ & $\mathbf{1 6 7}$ & $\mathbf{0 . 0 0}$ & $\begin{array}{l}\text { Acceptance } \\
\text { of the } \\
\text { hypothesis } \\
\text { in } \\
\text { the } \\
\text { alternative } \\
\text { form }\end{array}$ \\
\hline
\end{tabular}

It appears from table No. (8) that the calculated T value for the domain of availability of perception of the nature and concepts of the phenomenon of asymmetric costs and sticky behavior amounted to $(4.5)$, which is a statistically significant value at the significance level $(\alpha \leq 0.05)$ and the standard mark of the five-grader (3), which is it is greater than its tabular value of (1.96), and therefore the 
INTERNATIONAL JOURNAL OF ACADEMIC RESEARCH IN ACCOUNTING, FINANCE AND MANAGEMENT SCIENCES

Vol. 11, No. 2, 2021, E-ISSN: 2225-8329 @ 2021 HRMARS

main hypothesis is accepted by the alternative formula, which states: There is an awareness of the nature and concepts of the phenomenon of asymmetric costs.

HO2: There is no understanding of the causes and factors for the occurrence of asymmetric costs. To validate this hypothesis, a (One Sample T-test) was conducted as shown in Table (9) below.

Table (9) The Results of the Application of (One Sample T-test) to Understand the Causes and Determinants of the Occurrence of asymmetric in Costs

\begin{tabular}{|l|l|l|l|l|l|}
\hline Hypothesis & Arithmetic Mean & $\mathbf{T}$ & Freedom Degrees & sig & Result \\
\hline $\begin{array}{l}\text { There is no understanding of } \\
\text { the causes and factors for the } \\
\text { occurrence of asymmetric } \\
\text { costs. }\end{array}$ & $\mathbf{3 . 7 9}$ & $\mathbf{1 4 . 4 2}$ & $\mathbf{1 6 7}$ & $\mathbf{0 . 0 0}$ & $\begin{array}{l}\text { Acceptance } \\
\text { of the } \\
\text { hypothesis } \\
\text { in the } \\
\text { alternative } \\
\text { form }\end{array}$ \\
\hline
\end{tabular}

It appears from table No. (9) that the value of calculated (T) for the domain of availability of awareness of the causes and factors of the occurrence of asymmetric in costs amounted to (14.42), which is a statistically significant value at the level of significance $(\alpha \leq 0.05)$ and the standard mark of the five-grader scale (3), which is greater than its tabular value which is (1.96), therefore the main hypothesis is accepted in the alternative formula, which states: There is an awareness of the causes and factors for the occurrence of asymmetric costs.

HO3: There is no realization of possible solutions to avoid sticky cost behavior.

To validate this hypothesis, a (One Sample T-test) was conducted as shown in Table (10) below.

Table (10) Results of Applying One Sample T-test to Realize the Possible Solutions to Avoid the Sticky Behavior of Costs

\begin{tabular}{|l|l|l|l|l|l|}
\hline Hypothesis & $\begin{array}{l}\text { Arithmetic } \\
\text { Mean }\end{array}$ & $\mathbf{T}$ & $\begin{array}{l}\text { Freedom } \\
\text { Degrees }\end{array}$ & sig & Result \\
\hline $\begin{array}{l}\text { There is no realization of possible } \\
\text { solutions to avoid sticky behavior of } \\
\text { costs. }\end{array}$ & $\mathbf{3 . 7 9}$ & $\mathbf{7 . 2 9}$ & $\mathbf{1 6 7}$ & $\mathbf{0 . 0 0}$ & $\begin{array}{l}\text { Acceptance } \\
\text { of } \\
\text { hypothesis } \\
\text { in } \\
\text { the } \\
\text { alternative } \\
\text { form }\end{array}$ \\
\hline
\end{tabular}

It appears from table No. (10) that the calculated value of (T) for the realization of possible solutions to avoid sticky behavior of costs amounted to (7.29), which is a statistically significant value at the significance level $(\alpha \leq 0.05)$ and the standard mark of the five-grader scale (3), which is greater than its tabular value and amounting to (1.96), therefore the main hypothesis is accepted in the alternative formula, which states: There is an awareness of the causes and factors of the occurrence of asymmetric in costs. 
INTERNATIONAL JOURNAL OF ACADEMIC RESEARCH IN ACCOUNTING, FINANCE AND

MANAGEMENT SCIENCES

Vol. 11, No. 2, 2021, E-ISSN: 2225-8329 @ 2021 HRMARS

\section{Findings and Recommendations}

Findings

- $\quad$ The study showed that there is a medium degree of awareness, understanding and knowledge of the frameworks, concepts, and rationales for the phenomenon of sticky and asymmetric costs, to a medium degree in Jordanian industrial companies. The respondents also showed the need to pay attention to understanding cost behavior as it is necessary for the parties within the company, and that there is a need to conduct studies and research on topics related to sticky costs (asymmetric behavior of costs).

- $\quad$ The study revealed that there is a high degree of awareness of the reasons and factors that lead to the existence of a case of sticky behavior and asymmetric costs, its adoption of sticky behavior, the most important of which were the conflicting cases in views and interests emanating from the agency theory between owners and managers who manage the company and take relevant decisions based on personal benefit, whether moral or material, as well as the density of assets, especially fixed assets, and the failure to dispense with labor in periods of depression and their results according to labor legislation. In addition to the optimism of managers and excessive confidence in their estimates and future predictions.

- $\quad$ The study showed that there is an awareness of the appropriate solutions that have been proposed, through which it is possible to avoid the sticky behavior of costs to a medium degree, and the most important of these solutions was to follow the policies of trying to maintain moderate levels of asymmetric for stock and fixed assets, relying on an appropriate labor system and developing regulations that protect shareholders' rights against the managers.

This study contributes to the dissemination and improvement of scientific knowledge in the context of cost accounting, as well as the awareness of decision-makers of the cost data that can be relied upon in building their plans, and this will enhance the rationalization of the decisions of corporate departments and avoid the risks that may result due to the omission of the sticky cost effect.

This study is also considered significant as it is one of the recent studies that deals with exploring the scientific perception of those in charge of cost accounting activities, which enhances the correct accounting practice in the field of cost accounting.

\section{Recommendations}

- Holding courses and workshops on sticky costs for stakeholders whose nature of work requires knowledge and understanding of the rationale for sticky cost behavior, in order to enhance their awareness and serve the objectives of companies.

- Companies should analyze the reasons for the sticky behavior of their costs and their asymmetric, as well as study the proposed solutions, as the link between the causes and the proposed solutions will enable companies to take corrective actions related to the causes, especially internal directly, as for the reasons outside the control of the company, hedging policies can be followed to confront them.

- Companies should review their policies and regulations related to controlling the relationship between owners and managers, in order to reduce cases of conflict of interest, and benefit from the expertise of legal advisors related to the organization of labor and follow appropriate policies in the acquisition of fixed assets and inventory. 
INTERNATIONAL JOURNAL OF ACADEMIC RESEARCH IN ACCOUNTING, FINANCE AND

MANAGEMENT SCIENCES

Vol. 11, No. 2, 2021, E-ISSN: $2225-8329$ @ 2021 HRMARS

\section{References}

Abu-Serdaneh, J. (2014). The Asymmetrical Behavior of Cost: Evidence From Jordan. International Business Research, 7 (8).

Anderson, M. C., Banker, R. D., \& Janakiraman, S. N. (2003). Are selling, general, and administrative costs sticky?. Journal of Accounting Research, 41(1).

Anestaki, L. (2020). Stickiness phenomenon in Greek listed firms from 2010 to 2018. School Of Economics (Publication No.1748) [ Master thesis, International Hellenic University ]. https://repository.ihu.edu.gr//xmlui/handle/11544/29499

Ballas, A., Naoum, V.C., \&Vlismas, O.(2020).The Effect of Strategy on the Asymmetric Cost Behavior of SG\&A Expenses. European Accounting Review, 1(39).

Banker, R. D., Byzalov, D., \&Chen, L. T. (2013). Employment Protection legislation, Adjustment Costs And Cross-Country Differences In Cost Behavior. Journal of Accounting and Economics, 55 (1).

Cheung, J., Kim, H., Kim, S. \& Huang, R. (2016). Is The Asymmetric Cost Behavior Affected by Competition Factors? .Asia-Pacific Journal of Accounting and Economics, 25 (2).

Da Silva, Z., Vinicius, C., Dal Margo, C. B., Camila, F., \&Padilha, D. F. (2018). Effects of Economic Growth in the Behavior of Sticky Costs of Companies Belonging to BRICS Countries. Accounting and administration, 63(4).

Gu, Z., Tang, S., \&Wu, D. (2020). The Political Economy of Labor Employment Decisions: Evidence from China. Management Science, 66 (10). Retrieved from www.pubsonline.informs.org.

Hur, K.S., Kim, D.H., \& Cheung, J. H. (2019). Managerial Overconfidence And Cost Behavior of R\&D Expenditures. Sustainability, 11(18).

Jamkarani, R., \& Lalbar, A. (2016). Explaining The Relationship Between Sticky of Expenses with Prediction Error of Profit in Tehran Stock Exchange. Advances in Mathematical Finance \& Applications, 1(1).

Kama, I., \& Weiss, D. (2013). Do earnings targets and managerial incentives affect sticky costs? Journal of Accounting Research, 51 (1).

Maghid, B., \& Al-Essa, Y. (2017). Analysis Of The Behavior Of Sticky Costs: A survey Of Industrial Companies listed on the Amman Stock Exchange. The Jordanian Journal of Business Administration, 13.

Mohammad, H. (2020). Measuring The Impact Of Management Expectations On The Asymmetric Behavior Of Cost in Order to Increase the Quality of the Informational Content of the Management Accounting System (applied study). Journal of Accounting Thought, 24 (1),5.

Radhika, R., \& Satuluri, R. K. (2019). Impact of Operating Expenses on Life Insurance Profitability in India. International Journal of Human Resource Management and Research, 9(1).

Sekaran, U., \& Bougie, R. (2016). Research Methods for Business: A skill Building Approach. (7th ed.). New York, John Wiley \& Sons Inc.

Sun, R., Ho, K., Gu, Y., \& Chen, C. (2019). Asymmetric Cost Behavior And Investment in R\&D: Evidence from China's Manufacturing listed Companies. Sustainability, 11(6).

Xu, J., \& Sim, J. W. (2017). Are Costs Really Sticky And Biased? Evidence From Manufacturing Listed Companies in China. Applied Economics, 49(55).

Xue, S., \& Hong, Y. (2016). Earnings Management, Corporate Governance And Expense Stickiness. China Journal of Accounting Research, 9 (1), 44. 